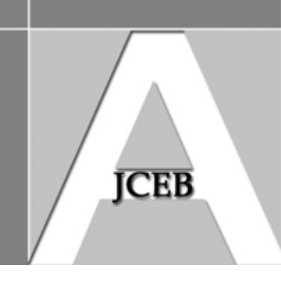

\title{
An Examination of the Structure of Sustainable Facilities Planning Scale for User Satisfaction in Nigerian Universities
}

Abayomi Ibiyemi, Yasmin Mohd Adnan, Md Nasir Daud (University of Malaya, Malaysia)

Martins Adenipekun (Lagos State Polytechnic, Nigeria)

\begin{abstract}
Universities are under increasing pressure to demonstrate that continuous performance improvement is being delivered for user satisfaction, but the importance of facilities planning as a student-staff focused tool needs to be emphasised. This research sought answers to questions relating to the underlying structure of sustainable facilities planning and user satisfaction, and the number of factors that make up the facilities planning scale. Three universities from the south-western part of Nigeria were selected randomly using ownership structure to define the cases: University of Lagos, Akoka, Lagos, Ladoke Akintola University of Technology, Ogbomoso and Joseph Ayo Babalola University, Ikeji Arakeji, each representing the Federal, State, and Private ownership. A questionnaire survey was used on a random sample of 651 staff and students from the three universities. Six hundred questionnaires were retrieved (response rate of 92.2\%). An exploratory factor analysis was used to understand the responses and the interrelationships. The results showed a twofactor solution of 'locational advantages and user needs' and 'adequacy of facilities/functional connection and four core determinants for acceptance. It is concluded that universities should factor student-staff focus points into their facilities planning schemes to optimise their service deliveries. The study contributes to the discussion on factor structure of sustainable facilities planning scale with a focus on students and staff of universities.
\end{abstract}

Keywords: Facilities planning, universities, data structure, factors, Nigeria.

\section{Introduction}

The concept of facilities planning evolved in response to the need for a more dynamic planning process, but, in the education sector, it poses a number of challenges not common in other sectors. Many challenges confront the effectiveness and efficient operation of educational facilities in the university system in recent times. Resultantly, several calls have been made to give more attention to the management of university facilities for improved qualitative outputs and user satisfaction.

Facilities in many universities in developing countries are becoming obsolete, and grossly inadequate to achieve the objectives of those universities. Some universities operate on temporary campuses that bear no resemblance to contemporary university expectations. Consequently university social environments do not appear to synchronise with expected student/teacher/staff relationships. There have been incessant strikes, lock outs and student agitations which sometimes resulted in destruction of support facilities. The management of universities' real estate assets has become increasingly inefficient, because many institutions do not have facilities planning units where the concept of facilities planning (FP) can be utilised in an operational capacity. Given the financial and resource constraints under which the universities must manage, it is essential that students and staff expectations are understood and measured (Robathan 1996; Adewunmi, Omirin \& Koleoso 2012). The basic thrust of sustainable facilities planning (SFP) was described by Van Mell (2005) as the provision of precise building or buildings needed to support strategic goals for satisfying corporate objectives and user satisfaction. Steiss (2005) emphasized that a systematic 
planning effort is vital to decision-making about construction and financing of strategic facilities and that values of sustainable facilities planning SFP should be demonstrated.

The management of university facilities transcends the problem of personnel, janitorial, transportation, or mere sanitation issues, but includes maximisation of efficiency in time savings, space, capital budgeting, staff welfare, teamwork and improvement in general productivity (Shayler 2010). The common appearance of decay, neglect, under-utilisation, over-utilisation and abandonment of structures is an indication of sparse strategic FP at the design and construction stages of university facilities. Van Mell (2005) stated that to achieve university corporate objectives, a detailed planning of every facet of university facilities is desirable. Literature abounds with evidence to justify the importance of the integration and application of FP to the management of facilities and user satisfaction (Marmolejo 2007; Fareo and Ojo 2013), but there is also the need to justify the importance of FP as a student and staff-focused tool for continuous performance improvement of universities. User satisfaction is a reflection of the degree to which users feel that their education environment is helping them to achieve their goals. However, some university management can be neglectful at times in considering student and staff viewpoints. This is a valid research problem that necessitated the development of the SFP scale. The overall competitive advantage index of an education system could diminish with having obsolete or inappropriate facilities if the importance of SFP is not articulated for proper understanding and implementation.

\section{Study Objective and Significance}

The study seeks to answer the following two questions:

- What is the underlying factor structure of sustainable facilities planning (SFP) and user satisfaction?

- What is the importance of SFP as a student and staff-focused tool for continuous performance improvement of universities?

This study is significant because it is of immediate relevance to national educational interests in developing countries, and helps to provide the basic index for further analytical studies in facilities planning in university settings.

\section{Study Context}

This study is demonstrated in the context of south-west (SW) Nigeria. The choice of Nigeria is informed by the common appearance of decay, neglect, under-utilisation and overutilisation of facilities on many of their university campuses, which prima facie indicate lack of strategic and sustainable facilities planning. The SW zone consists of Ogun, Oyo, Ondo, Osun, Lagos and Ekiti states. These states share similar educational, socio-cultural, economic and political characteristics, and they constitute the fastest growing region in education when compared with the geo-political zones in the country. There are thirty-one approved universities within the South-West zone (NUC 2011). University of Lagos (UNILAG) is located at Akoka, Yaba, while the Medical Campus of the College of medicine is located a few kilometers from the main campus at Idi-Araba, Surulere, on the mainland of Lagos. The university, established in 1962, has residential, office and academic facilities and services for both staff and students. It has fourteen academic units comprising a broad range of professional faculties and schools. Most faculties are located on the main campus. Ladoke Akintola University (LAUTECH) was established in 1990. The main campus is at Ogbomosho in Oyo state. The campus is the site of the university's administration, as well as home to five faculties and the post-graduate school. The other campus is located in Osogbo, home to the College of Health Sciences, and Faculties of Medicine and Surgery, Medical Laboratory

Ibiyemi A, Adnan Y M, Daud M N \& Adenipekun M. 2014, 'An examination of the structure of facilities planning scale for user satisfaction in Nigerian universities’, Australasian Journal of Construction Economics and Building, 14(3), 58-73. 
Technology and Nursing. Joseph Ayo Babalola University (JABU) is a private Nigerian university located in Ikeji-Arakeji in Osun state. It was established by the Christ Apostolic Church (CAC) Worldwide in 2002. The university is a fully residential institution, with about seven faculties. There are 38,000 registered students in UNILAG, 25,000 in LAUTECH and 15,000 in JABU. Staff populations are 4,000, 3,000, and 2,800 respectively (NUC 2011).

\section{Review of Literature}

Facilities management (FM) is complex in scope (Paxman 2007). It integrates the people, process and the place. FM embodies inter-related job responsibilities that include long-range facility planning, annual tactical planning, facility financial forecasting and management, real estate acquisition and disposal, interior space planning, work specifications, installation and space management, architectural and engineering planning and design, new construction and/or renovation works, maintenance and operations maintenance of the physical plant, telecommunication integration, security and general administrative services such as food services, records management, reprographics, transportation and mail services, health, safety and out sourcing (Rondeau, Brown \& Lapides 1995). It anchors and integrates all of the job responsibilities together to design a corporate policy objective. It is therefore seen as an emerging field that incorporates many interacting terminologies (Van Mell 2005). FM poses a strong relationship with other disciplines, such as space planning, architecture, interior design, environmental psychology, real estate, systems engineering, human resource management, information systems management, project management, and building service engineering (Adegoke and Adegoke 2013). Central to basic FM functions and activity areas is planning and programming. Every aspect of facilities management requires detailed planning to achieve its objectives. Long (5 years) and short (1 year) term programs should be aligned with corporate and departmental operating plans and these should incorporate major activities (Paxman 2007; Krizek et al. 2012). Minimisation of facilities costs, tracking and pattern of changes also exert certain impact on firms' goals, underscoring planning as an imperative in all activities of FM (Somovoa 2007). ASBO (2003) asserted that effective management starts with planning that synthesises collaborative interfaces, but cautioned that planning can result in real problems when large capital investment sums are misappropriated. Bennett (2010) summarized effective facilities planning and management of public sector property as speculative and one which requires a conceptual framework to operate. He therefore investigated the validity of facilities planning by considering the relationship between customer and business led strategies and how different strategies affect facilities planning. A prototype strategic model for future use decision making process where it is necessary to consider facilities needs and challenges in business was proposed. Bennett restated that facilities or assets strategies within this context are centered on business strategies and organizational aspirations rather than making current assets dictate direction of strategic business goals. The business strategies and organizational approach allows the definition of a destination whereas the current assets approach provides an indication of the starting point and consequently the length of journey. The business and organizational focus rather than facilities or asset focus allows strategies to be developed which, once in place, can provide an informed platform for the more organized facilities management model to come into play with cost-in-use planning, maintenance planning, space planning (Shayler 2010; Wright \& Olesand 2007; Burud 2010), budget planning, asset planning, operation planning, systems and software planning (Dingley 2008), capital planning, campus planning (Koppelman 1975), contract facility planning, environmental planning and scenario planning (Sekula 2010; IJFM 2010) and organization planning (Gladwell 2000; Lepkova \& Uselis 2013).

Ibiyemi A, Adnan Y M, Daud M N \& Adenipekun M. 2014, 'An examination of the structure of facilities planning scale for user satisfaction in Nigerian universities’, Australasian Journal of Construction Economics and Building, 14(3), 58-73. 
The American institute of Architects (2011) and UNM (2014) concurred that a sustainable facility plan should answer the following questions about an organization's real estate portfolio: How much space will the organization need to carry out its activities - quantity? What kinds of space will it need - type? During what time period will the organization need it timing? How will it procure it, buy, build, or lease - portfolio mix and duration? What will it cost - budget? Where does the space need to be located - location? Which groups need to be located near each other - affinity and allocation? How will the organization deal with unplanned changes in demand for space - hedging and exit strategy? What mechanisms will it employ to let users see the actual costs of their occupancy; forecast their future needs accurately, honour their promises concerning occupancy, and use space efficiently? (Internal business model, including items such as internal leases and transfer charges) How will the facilities contribute to the core business of the organization through their effect on marketing, employee recruiting, and employee retention - corporate identity, location, and amenities? Can the organization reduce total real estate costs per person - density, design standards, and alternative office spacing? Can it affect employee productivity and rate of production throughput by the design of the facilities - Effectiveness and productivity? In their view, FP process for capital projects for campus development should consist of (1) Identifying, budgeting, documenting, justifying, and prioritizing built environment needs, in which facilities plan identifies the type, quantity and location of spaces needed by the department or college through an in-depth analysis of existing facilities; (2) Understanding of program growth, projected student volumes, research aspirations; and developing an achievable and affordable plan to meet the college's current and future facility needs, with an outcome of achieving academic initiatives and supporting the mission and goals of the Institutions. Figure 1 illustrates the SFP process.

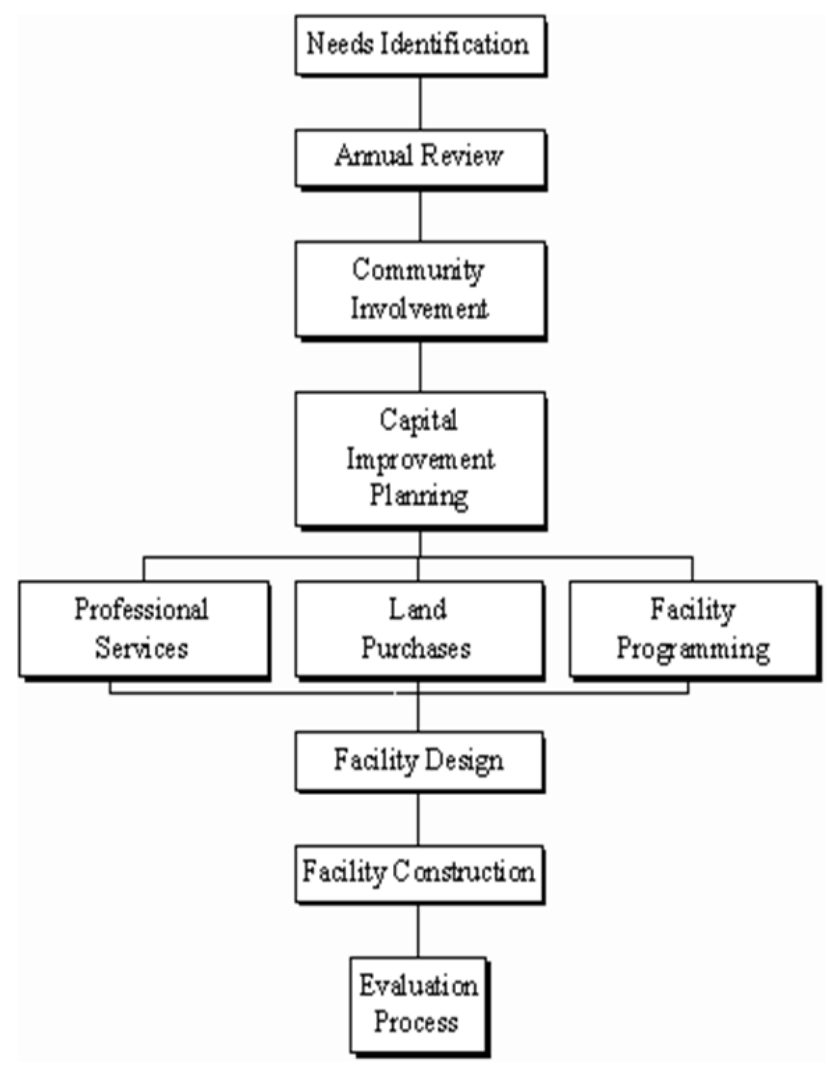

Figure 1: The SFP Process (Adapted from AIA, 2011 and UNM, 2014)

Ibiyemi A, Adnan Y M, Daud M N \& Adenipekun M. 2014, 'An examination of the structure of facilities planning scale for user satisfaction in Nigerian universities', Australasian Journal of Construction Economics and Building, 14(3), 58-73. 
UNM remarked that a full needs assessment takes account of all the relevant academic programs, research and/or class listings specific to the targeted area of concern, assessment of existing space/building conditions, utilisation of current spaces, and projected volumes as validated from the Provost office. This is the review stage in which, according to IFMA (2009), the Facilities Manager, Planner and designers begin to identify the gaps in current facility needs with long-term needs. Issues that include workforce demographics, manufacturing processes, organizational structure and culture, community and government regulatory requirements, market positioning, and capacity rates and volumes are applied to balance the gaps. The immediate community may be involved to facilitate stakeholders' contributions and cooperation. Scenario planning is conducted by selecting several external forces and imagining related changes that might influence the organization, such as the global marketplace, technology, change in regulations, and demography. For each potential change, the best, worst, and reasonable cases are reviewed in order to suggest what the organization might do, or potential strategies, in each of the three scenarios to respond to each change. The facility design and evaluation, which the design of the facilities is based on, is a re-evaluation of the strategies. To deploy the use of computer to aid FP in this sector would no doubt involve preparation of strategic integration of user requests. Room use between the teaching, off teaching hours, leisure-based activities, use of multi-purpose halls, squash and tennis courts, bars and other spaces used by students, staff or outside organizations will differ widely. Some organizations hire out facilities to outside organization during vacations to increase revenues, particularly accommodation and meeting spaces. These require adequate planning of every aspect of the facilities to integrate their various strategic foci for corporate objectives to be achieved. In the literature, it is assumed that the application of FP (and FM in general) is focused on supporting primary processes and contributing to achieving organisational goals (Atkin \& Brooks 2000; Barret \& Baldry 2003) the physical setting of which can aid or hinder the accomplishment of internal organizational goals, and user satisfaction (Bitner 1992). A clear expression of this is the large number of FM-related studies that have been conducted focussing on different aspects of its added value for primary processes (Williams 1996; Krumm, Dewulf \& De Jonge 1998; Amaratunga \& Baldry 2000; Salonen 2004; Wauters 2005; Lindholm \& Leva"ïnen 2006; De Toni et al. 2007; Chotipanich \& Nutt 2008; De Vries, De Jonge \& Van Der Voordt 2008; Adewunmi, Omirin \& Koleoso 2012), especially quality (e.g. customer satisfaction), users satisfaction regarding time (e.g. response time), risk (e.g. safety, reputation) and relationship quality (e.g. alignment). It has already been established that FP value concerns a trade-off by the users between benefits, costs and risks. In this study, the scope of FP focuses on the contribution to user satisfaction, and its added value can be defined as the user perceived contribution of the different facility services to satisfying their needs.

Main knowledge gaps in FM literature relating to higher institutions include studies on the students perspective of housing facilities for continuous improvement in student housing satisfaction (Sawyer \& Yusof 2013), and assessing the magnitude of deterioration in African tertiary institutions and their relative lack of conduciveness to learning (Adegoke and Adegoke 2013). Literature has also not provided evidence of the factor levels of contributions of SFP scale to user satisfaction, nor justified the importance of the FP as a student and staff-focused tool for continuous performance improvement of SW Nigeria Universities. This study is an investigation that seeks to address that gap.

\section{Research Method}

The research adopted a survey approach. The survey research offered the scope for large representative sampling of students and staff from where reliable information can be extracted about user satisfaction from the two heterogeneous populations. This is preferred

Ibiyemi A, Adnan Y M, Daud M N \& Adenipekun M. 2014, 'An examination of the structure of facilities planning scale for user satisfaction in Nigerian universities’, Australasian Journal of Construction Economics and Building, 14(3), 58-73. 
to interviews and observations, which have very limited scope in this regard. SW Nigeria has the highest concentration of universities (31) in the country and a good mixture of Federal (6), State (9) and Private (16) universities (JAMB 2010). Three of the universities were randomly selected from each cluster of ownership and control structure - one from federal, state, and private ownership respectively.

The secondary information used for this study was gathered from internet sources, relevant journals, seminar and conference papers, and monographs. Others include materials from text books, base maps, and government publications. The National Universities Commission (NUC), the physical development offices of the respective universities, works and services, and other relevant departments were observed directly for triangulation. The primary data collection used questionnaires. A total number of 651 students and staff were served with close-ended questionnaires (217 questionnaires per university). 600 questionnaires were retrieved (92.2\% response rate). Respondents were selected using the random technique and categorized into" Students" and "Staff". The variables of study were identified in current literature (American institute of Architects, 2011 and UNM, 2014) and classified into three factors for measuring user satisfaction as shown in Table 1.

Table1: Classification of factors for measuring user satisfaction

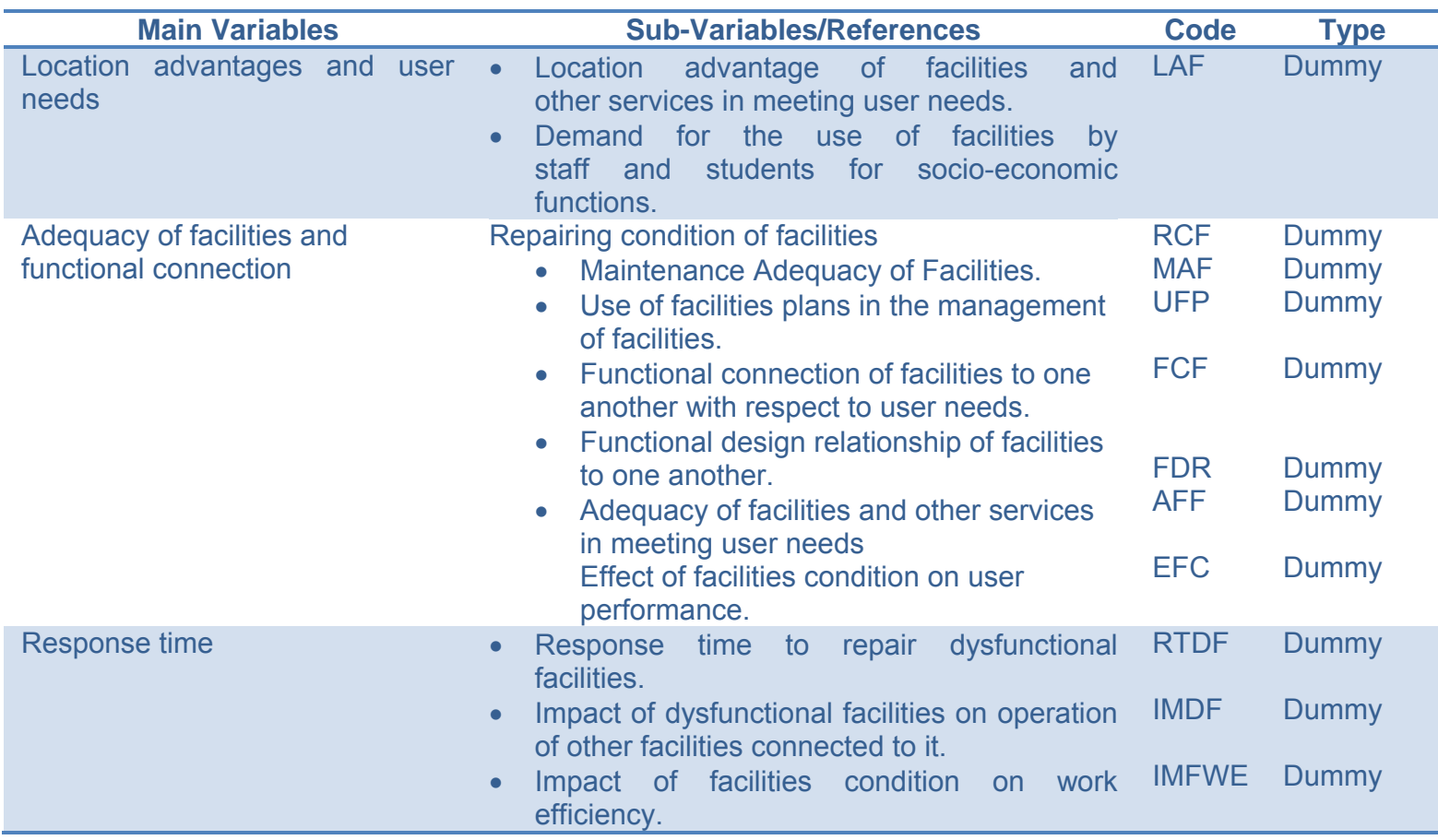

$33.9 \%, 34.3 \%$ and $31.8 \%$ of students' respondents are from UNILAG, LAUTECH, and JABU respectively, while $31 \%, 34.5 \%$, and $34.5 \%$ of staff respondents are from UNILAG, LAUTECH, and JABU respectively. The distribution of questionnaires among students and staff is fair and representative. No university has less than $30 \%$ of the total number of questionnaires retrieved.

The campus facilities, units and services considered in this study include: The main library, departments' libraries, division of students affairs, university health services, sports centres, the bursary, registry, internal audit, consults, and ventures, bookshops and press. Others are car park, guest houses, conference center, central industrial liaison placement, main auditorium, botanical/ zoological gardens, community pharmacy, academic planning unit,

Ibiyemi A, Adnan Y M, Daud M N \& Adenipekun M. 2014, 'An examination of the structure of facilities planning scale for user satisfaction in Nigerian universities’, Australasian Journal of Construction Economics and Building, 14(3), 58-73. 
guidance and counselling unit, estate units, media/corporate affairs, works and physical planning unit, hydraulic research unit, alumni relations unit, legal unit, security unit, records and quality assurance, students' halls of residence, and the senate building complex. Others are lecture theatres, shopping complexes, sports complex, senate building, SUG building, and banks. These are the composites of what constitute real estate whether tangible or intangible, services and other benefits real or abstract in form that contribute to the achievement of the corporate objectives of the institutions.

Methods of analysis: Frequency distribution of field data and the exploratory factor analysisprincipal component analysis were used. The reliability of the three subscales was assessed using Cronbach alpha for internal consistencies: All the three factors (a) to (c) have coefficients $\geq .7$ on the average (Devellis 2003; Kline 2005; Pallant 2011).

\section{Results and Analyses}

Each questionnaire was designed in close-ended form to enable respondents to provide responses to 12 independent variables that constituted FSP scale. The SFP scale was employed in the assessment of user satisfaction, the outcome variable. The analysis of the questionnaire and the response rates are shown in Table 2.

Table 2: Frequency and Mean Scores of Questionnaire Responses from the Universities (Analysis of Responses, 2014)

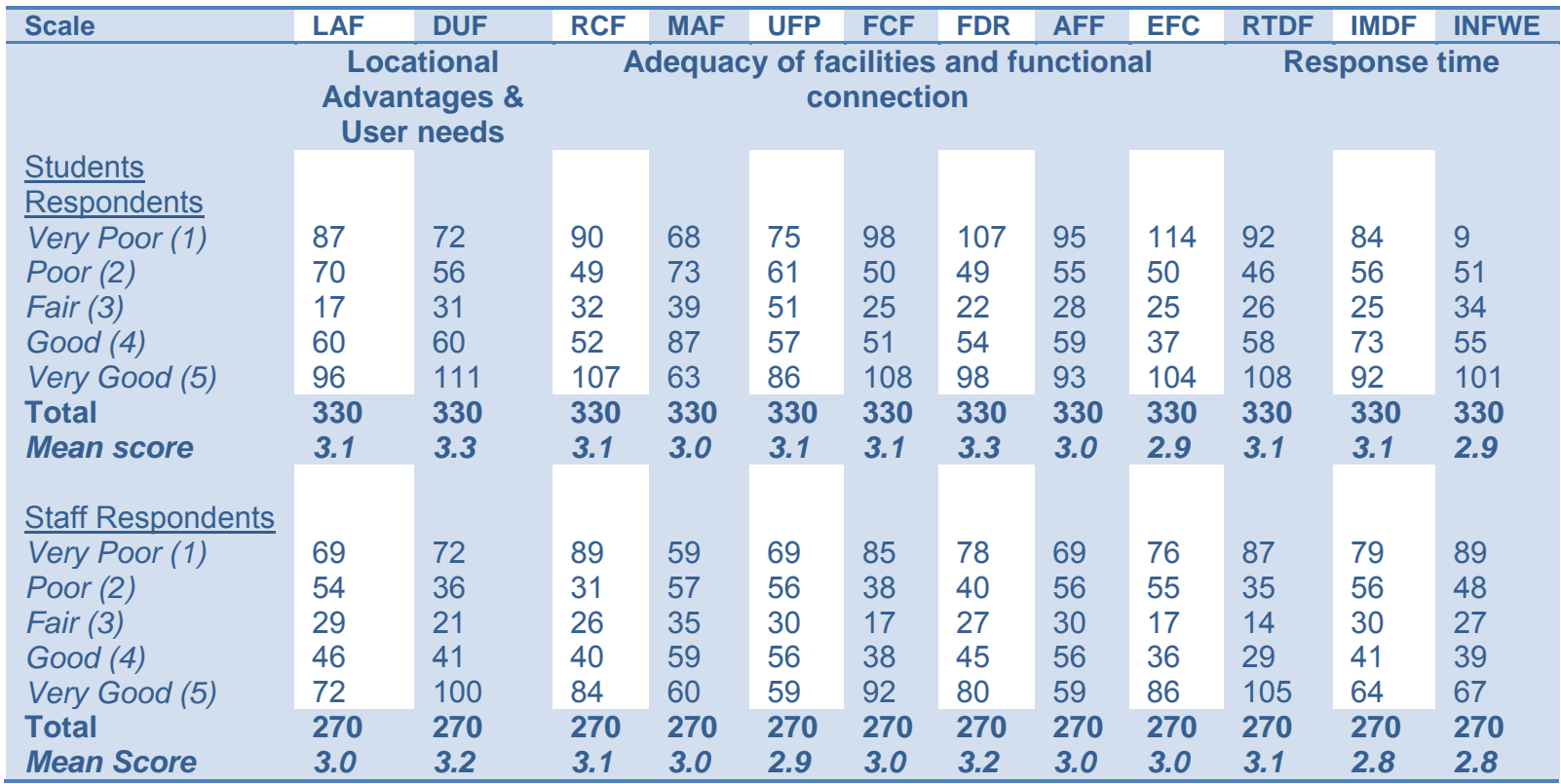

A total of 330 students responded to all the variables of study, while 220 staff respondents were recorded across the universities. All the samples were subjected to EFA. The Likert 5 points summated rating scales was used and it ranged from Very Poor (1) to Very Good (5). For the purpose of interpreting Table 2, the mean scores were calculated and related to the scale labels, very poor (1) to very good (5) based on $\sum$ (scale $x$ frequency)/number of respondents.

Respondents were asked to assess the location benefits/advantage of facilities to users. Mean scores of 3.0 and 3.1 obtained for student and staff respondents indicated that location

Ibiyemi A, Adnan Y M, Daud M N \& Adenipekun M. 2014, 'An examination of the structure of facilities planning scale for user satisfaction in Nigerian universities', Australasian Journal of Construction Economics and Building, 14(3), 58-73. 
benefits/advantages of facilities with respect to needs of users were generally fair. The locations of facilities were fairly suited to the needs of users.

They were also asked to assess the demand for the use of facilities in the university for social and economic functions. Mean scores of 3.3 and 3.2 obtained for student and staff respondents indicated fair public demand for the use of the various universities' facilities. It can be interpreted that there is demand for use of facilities across the universities.

The study sought information on the state of repair conditions of facilities in each of the selected universities. Mean scores of 3.1 from the respondents indicated fair state of repair conditions. This study also investigated the adequacy of maintenance of facilities in the universities. Mean scores of 3.0 were obtained, indicating that maintenance of facilities is fairly adequate.

We asked respondents to assess their respective universities on the use of maintenance plans in the management of universities facilities. Mean scores of 3.1 and 2.9 were obtained for student and staff respondents respectively. It indicated fair use of facilities plan in their various universities from the students' perspective, while it is poor from the staff perspective. However, generally, the use is not optimal.

We also asked respondents to assess the functional connection of facilities to one another for smooth and unhindered operation in their respective universities. Mean scores of 3.1 and 3.0 obtained for student and staff respondents show that the functional connection of facilities to one another with respect to the needs of users is fair.

The research also elicited information on the functional design relationship between facilities to each other with respect to the efficient discharge of users' works. Mean scores of 3.3 and 3.2 obtained for student and staff respondents indicated fair functional design relationship of facilities to one another for the purpose of allowing users to discharge their duties effectively and with comfort.

We also implored respondents to assess whether the facilities were adequate in quantity and services for the work users expect those facilities to perform. Mean scores of 3.0 were obtained, indicating that maintenance of facilities is fairly adequate. All the universities generally had fairly adequate facilities to meet needs of users.

With respect to weighing the effect of condition of facilities on users' performance, rating were allocated for the universities on: the period of time it takes to respond to request to repair dysfunctional facilities; assessing the impact of broken-down and out of operation facilities on the operation of other facilities on performance in the work environment; and the impact of facilities condition on their work efficiency. A $43.8 \%$ rating was achieved. Mean scores of $3.1 ; 3.1$ and $2.8 ; 2.9$ and 2.8 were obtained respectively. While period of time it takes to respond to request to repair dysfunctional was minimal, the effect of condition of facilities on users' performance, and facilities and the impact of facilities condition on their work efficiency was generally poor.

\section{Exploratory Factor Analysis (EFA)}

The EFA is based on correlation matrix; that all the variables are correlated to some degree. Table 3 is the basis of the application of the EFA-Principal Components. EFA has been used in this study to understand and identify the pattern of responses of students and staff of three universities completing closed-ended questionnaires. The items measuring similar things can be identified, and therefore forms the structure of replies to the questionnaire. A coherent set of data which addresses the research questions is achieved. Studies with similar themes that have also adopted the EFA-Principal Components are those of Pallant and Bailey (2005)

Ibiyemi A, Adnan Y M, Daud M N \& Adenipekun M. 2014, 'An examination of the structure of facilities planning scale for user satisfaction in Nigerian universities’, Australasian Journal of Construction Economics and Building, 14(3), 58-73. 
which used it for the assessment of the hospital anxiety and depression scale in musculoskeletal patients; Zemering (2009) in ascertaining the perception of government workers to sustainability programs in the US; Addae-Dappah, Hiang \& Shi (2009), in the assessment of perception of investors and users to sustainable property features in Singapore; and Oven and Pekdemir (2006), in establishing office rent determinants in Istanbul.

\section{PART I - Oblimin Rotation of four-factor solution (Default in SPSS22)}

The procedure suppresses the presentation of any factor loadings with values less than 3 (Pallant 2011). The correlation matrix of the SFP sub-variables is shown in Table 3 where there are correlation coefficients greater than .03. Specifically, it appears that there are nine groups of variables that are strongly intercorrelated, i.e. having coefficients greater than .500 : (i) FDR/AFF (.666) (ii) UFP/MAF (.651) (iii) RCF/MAF (.612); (iv) FCF/MAF (.612); (v) RTDF/UFP (.558) (vi) AFF/EFC (.542); (vii) FDR/EFC (.533) (viii) RCF/UFP (.528); and (ix) UFP/FCF (.517). The largest correlations occur in (i) and (ii). The Kaiser-Meyer-Olkin $(\mathrm{KMO})$ value is greater than .6 $(\mathrm{KMO}=.860)$ (Kaiser 1970; Addae-Dappah, Liow Kim Hiang \& Neo Yen Shi. 2009), and the Bartlett test of sphericity is significant at $p \leq .05(p=.001)$ (Bartlett 1954). The indication is that factor analysis is appropriate (Robert Ho 2006; Field 2009; Pallant 2011; Howitt and Crammer 2011). Table 4 shows the Total Variance Explained result.

Table 3: SPPSS22 (DEFAULT) Correlation Matrix of SFP sub-variables

\begin{tabular}{|rl|r|r|r|r|r|r|r|r|r|r|r|r|}
\hline & & LAF & DUF & RCF & MAF & UFP & FCF & FDR & AFF & EFC & RTDF & IMDF & INFWE \\
\hline Correlation & LAF & 1.000 & .426 & .238 & .300 & .207 & .159 & .278 & .242 & .244 & .138 & .231 & .199 \\
& DUF & .426 & 1.000 & .203 & .278 & .235 & .213 & .265 & .217 & .179 & .112 & .188 & .126 \\
& RCF & .238 & .203 & 1.000 & $\underline{.612}$ & .523 & .465 & .307 & .378 & .298 & .326 & .277 & .191 \\
& MAF & .300 & .278 & $\underline{.612}$ & 1.000 & $\underline{.651}$ & $\underline{.612}$ & .423 & .466 & .378 & .420 & .337 & .285 \\
& UFP & .207 & .235 & $\underline{.523}$ & $\underline{.651}$ & 1.000 & $\underline{.517}$ & .336 & .356 & .285 & .558 & .259 & .160 \\
& FCF & .159 & .213 & .465 & $\underline{.612}$ & $\underline{.517}$ & 1.000 & .300 & .343 & .265 & .352 & .293 & .182 \\
& FDR & .278 & .265 & .307 & .423 & .336 & .300 & 1.000 & $\underline{.666}$ & .533 & .201 & .371 & .275 \\
& AFF & .242 & .217 & .378 & .466 & .356 & .343 & $\underline{.666}$ & 1.000 & .542 & .277 & .382 & .269 \\
& EFC & .244 & .179 & .298 & .378 & .285 & .265 & $\underline{.533}$ & $\underline{.542}$ & 1.000 & .234 & .243 & .161 \\
& RTDF & .138 & .112 & .326 & .420 & .558 & .352 & .201 & .277 & .234 & 1.000 & .140 & .159 \\
& IMDF & .231 & .188 & .277 & .337 & .259 & .293 & .371 & .382 & .243 & .140 & 1.000 & .422 \\
& INFWE & .199 & .126 & .191 & .285 & .160 & .182 & .275 & .269 & .161 & .159 & .422 & 1.000 \\
\hline
\end{tabular}

As in Table 4, we considered Kaiser's criterion in determining how many factors to extract: Factors or components that have Eigenvalues greater than 1 (Kaiser's criterion) are reported. The first four components recorded Eigenvalues $\geq 1(4.594,1.400,1.111$, and 1.028). These four components explain a total of $67.78 \%$ of the variance $(38.29 \%, 11.67 \%, 9.26 \%$, and $8.56 \%$ respectively). Components having Eigenvalues less than 1 are ignored because such factors consist of uninterpretable error variation (Pallant 2011; Howitt and Crammer 2011). The Scree Plot, when examined, has a break in the size of Eigenvalues for the factors occurring after the second factor. The curve is also fairly flat after the second factor. The indication is that the scree plot supports a two-factor solution. However, the other factors were analyzed further as their Eigenvalues were also greater than 1. Table 5 shows the unrotated loadings of each of the items of the four components/factors.

As in Table 5, the four components are then obliguely rotated and the loadings of the 12 variables on these 4 factors are as shown in the table. It can be seen that most of the items

Ibiyemi A, Adnan Y M, Daud M N \& Adenipekun M. 2014, 'An examination of the structure of facilities planning scale for user satisfaction in Nigerian universities’, Australasian Journal of Construction Economics and Building, 14(3), 58-73. 
loaded quite strongly, i.e. above .4 (Pallant 2011; Howitt and Crammer 2011) on two components, LAF (.456 and .609), and DUF (.426 and .684). We then used the criterion values randomly generated from similar sized data sets and obtained from Monte Carlo Parallel Analysis, to take a decision on the number of factors: If the size of Eigenvalue was greater than the criterion value, the factor was retained, and if less, the factor was rejected (Pallant 2011). The summary of PCA and Monte Carlo parallel analysis for decision making is shown in Table 6.

Table 4: Total Variance Explained

\begin{tabular}{|c|c|c|c|c|c|c|c|}
\hline \multirow[t]{2}{*}{ Component } & \multicolumn{3}{|c|}{ Initial Eigenvalues } & \multicolumn{3}{|c|}{$\begin{array}{c}\text { Extraction Sums of Squared } \\
\text { Loadings }\end{array}$} & \multirow{2}{*}{$\begin{array}{c}\text { Rotation Sums of } \\
\text { Squared Loadings } \\
\text { Total }\end{array}$} \\
\hline & Total & $\begin{array}{c}\% \text { of } \\
\text { Variance }\end{array}$ & $\begin{array}{l}\text { Cumulative } \\
\%\end{array}$ & Total & $\begin{array}{c}\% \text { of } \\
\text { Variance }\end{array}$ & $\begin{array}{c}\text { Cumulative } \\
\%\end{array}$ & \\
\hline 1 & 4.594 & 38.287 & 38.287 & 4.594 & 38.287 & 38.287 & 3.742 \\
\hline 2 & 1.400 & 11.665 & 49.952 & 1.400 & 11.665 & 49.952 & 3.214 \\
\hline 3 & 1.111 & 9.259 & 59.212 & 1.111 & 9.259 & 59.212 & 2.090 \\
\hline 4 & 1.028 & 8.564 & 67.776 & 1.028 & 8.564 & 67.776 & 2.162 \\
\hline 5 & .743 & 6.190 & 73.966 & & & & \\
\hline 6 & .613 & 5.107 & 79.074 & & & & \\
\hline 7 & .549 & 4.578 & 83.652 & & & & \\
\hline 8 & .511 & 4.257 & 87.909 & & & & \\
\hline 9 & .468 & 3.904 & 91.813 & & & & \\
\hline 10 & .390 & 3.253 & 95.066 & & & & \\
\hline 11 & .316 & 2.635 & 97.701 & & & & \\
\hline 12 & .276 & 2.299 & 100.000 & & & & \\
\hline
\end{tabular}

Table 5: Component Matrix

\begin{tabular}{|c|c|c|c|c|}
\hline \multirow[b]{3}{*}{ MAF } & \multicolumn{4}{|c|}{ Component } \\
\hline & 1 & 2 & 3 & 4 \\
\hline & .815 & & & \\
\hline UFP & .721 & -.456 & & \\
\hline AFF & .717 & & -.319 & \\
\hline FDR & .685 & .399 & & \\
\hline RCF & .681 & & & \\
\hline FCF & .665 & -.351 & & \\
\hline EFC & .601 & & & -.422 \\
\hline IMDF & .545 & .329 & & .500 \\
\hline RTDF & .537 & -.464 & & \\
\hline DUF & .426 & & .684 & \\
\hline LAF & .456 & .328 & .609 & \\
\hline INFWE & .428 & .321 & & .677 \\
\hline
\end{tabular}

Ibiyemi A, Adnan Y M, Daud M N \& Adenipekun M. 2014, 'An examination of the structure of facilities planning scale for user satisfaction in Nigerian universities’, Australasian Journal of Construction Economics and Building, 14(3), 58-73. 
Table 6: Summary of PCA and parallel analysis for decision making

\begin{tabular}{llll}
\hline $\begin{array}{l}\text { Component } \\
\text { No }\end{array}$ & $\begin{array}{l}\text { Actual Eigenvalue } \\
\text { from PCA }\end{array}$ & $\begin{array}{l}\text { Criterion value from } \\
\text { MC Parallel analysis }\end{array}$ & Decision \\
1 & 4.594 & 1.2389 & Accept \\
2 & 1.400 & 1.1778 & Accept \\
3 & 1.111 & 1.268 & Reject \\
4 & 1.028 & 1.0851 & Reject \\
5 & .743 & 1.0496 & Reject \\
\hline
\end{tabular}

The result of parallel analysis supported our decision from the scree plot to retain only two factors for further investigation. Further to making a final decision concerning the number of factors, we examined the Pattern Matrix table, Table 7. The table shows the items loading on the 4-factor solution with 5 items loading above .3 on component 1, 3 items on component 2,2 items on component 3 , only one item on component 4 . Ideally, we would have liked 3 or more items loading on each component. This further supports only two factors. Using the SPSS22 default option, we obtained a four-factor solution, hence, we needed to go back and 'force' a two factor solution. This is contained in Part II.

Table 7: Pattern Matrix

\begin{tabular}{|c|c|c|c|c|}
\hline & \multicolumn{4}{|c|}{ Component } \\
\hline & 1 & 2 & 3 & 4 \\
\hline UFP & .862 & & & \\
\hline RTDF & .758 & & & \\
\hline FCF & .736 & & & \\
\hline MAF & .732 & & & \\
\hline RCF & .681 & & & \\
\hline EFC & & .872 & & \\
\hline FDR & & .819 & & \\
\hline AFF & & .802 & & \\
\hline DUF & & & .867 & \\
\hline LAF & & & .813 & \\
\hline INFWE & & & & .891 \\
\hline IMDF & & & & .747 \\
\hline \multicolumn{5}{|c|}{$\begin{array}{l}\text { Extraction Method: Principal Component Analysis. } \\
\text { Rotation Method: Oblimin with Kaiser Normalization. }{ }^{a} \\
\text { a. Rotation converged in } 6 \text { iterations. }\end{array}$} \\
\hline
\end{tabular}

\section{PART II - Oblimin Rotation of two-factor solution (Adjusted in SPSS22)}

As in Table 8, the Total Variance Explained $-49.95 \%$ of the variance is explained, compared with $67.78 \%$ explained by the four-factor solution. After rotating the two-factor solution, the new Component Correlation Matrix, the Pattern, and the Pattern Matrix Tables were reexamined. The strength of the relationship between the two factors is a moderate intercorrelation $(r=.464)$. This gives us information that the correlation between the two components are low, and that we should also expect similar solutions from varimax rotation. We therefore reported oblimin rotation further in Table 9. Table 9 shows the combination presentation of the pattern matrix, structure matrix, communalities tables for PCA with oblimin rotation of two-factor solution of SFP items. \pm 0.30 is the minimum level of practical significance. Values less than \pm 0.30 indicate that the item does not fit well with the other items in the component (Pallant 2011; Tabachnick \& Fidell 2007).

Ibiyemi A, Adnan Y M, Daud M N \& Adenipekun M. 2014, 'An examination of the structure of facilities planning scale for user satisfaction in Nigerian universities’, Australasian Journal of Construction Economics and Building, 14(3), 58-73. 
Table 8: Total variance explained for the 12 sub-variables

\begin{tabular}{|c|c|c|c|c|c|c|c|}
\hline \multirow[b]{2}{*}{ Component } & \multicolumn{3}{|c|}{ Initial Eigenvalues } & \multicolumn{3}{|c|}{$\begin{array}{c}\text { Extraction Sums of Squared } \\
\text { Loadings }\end{array}$} & \multirow{2}{*}{$\begin{array}{c}\begin{array}{c}\text { Rotation Sums of } \\
\text { Squared Loadings }\end{array} \\
\text { Total }\end{array}$} \\
\hline & Total & $\begin{array}{c}\% \text { of } \\
\text { Variance }\end{array}$ & $\begin{array}{c}\text { Cumulative } \\
\%\end{array}$ & Total & $\%$ of Variance & Cumulative \% & \\
\hline $\begin{array}{l}1 \\
2 \\
3 \\
4 \\
5 \\
6 \\
7 \\
8 \\
9 \\
10 \\
11 \\
12\end{array}$ & $\begin{array}{l}4.594 \\
1.400 \\
1.111 \\
1.028 \\
.743 \\
.613 \\
.549 \\
.511 \\
.468 \\
.390 \\
.316 \\
.276\end{array}$ & $\begin{array}{r}38.287 \\
11.665 \\
9.259 \\
8.564 \\
6.190 \\
5.107 \\
4.578 \\
4.257 \\
3.904 \\
3.253 \\
2.635 \\
2.299\end{array}$ & $\begin{array}{r}38.287 \\
49.952 \\
59.212 \\
67.776 \\
73.966 \\
79.074 \\
83.652 \\
87.909 \\
91.813 \\
95.066 \\
97.701 \\
100.000\end{array}$ & $\begin{array}{l}4.594 \\
1.400\end{array}$ & $\begin{array}{l}38.287 \\
11.665\end{array}$ & $\begin{array}{l}38.287 \\
49.952\end{array}$ & $\begin{array}{r}3.731 \\
3.744\end{array}$ \\
\hline
\end{tabular}

Extraction Method: Principal Component Analysis.

a. When components are correlated, sums of squared loadings cannot be added to obtain a total variance.

Table 9: Pattern matrix, structure matrix, communalities tables for PCA with oblimin rotation of two-factor solution of the 12SFP items.

\begin{tabular}{|l|l|l|l|l|l|}
\hline Item & \multicolumn{2}{l|}{ Pattern Coefficients } & \multicolumn{2}{l|}{ Structure Coefficients } & Communalities \\
\hline & FACTOR 1 & FACTOR2 & FACTOR 1 & FACTOR2 & \\
Component 1 & Component 1 & Component 1 & Component 1 & \\
\hline FDR & .785 & -.017 & .793 & -.381 & .629 \\
AFF & .704 & -.136 & .767 & -.462 & .602 \\
IMDF & .636 & -.003 & .658 & -.371 & .406 \\
EFC & .619 & -.084 & .637 & -.297 & .439 \\
LAF & .582 & .049 & .560 & -.221 & .315 \\
INFWE & .559 & .058 & .532 & -.201 & .286 \\
DUF & .481 & -.018 & .489 & -.241 & .239 \\
UFP & -.021 & .862 & .379 & .853 & .728 \\
RTDF & -.136 & .703 & .561 & .834 & .504 \\
MAF & -.222 & .731 & .385 & .751 & .733 \\
FCF & .048 & .728 & .431 & .733 & .565 \\
RCF & .117 & .679 & .218 & .700 & .548 \\
\hline
\end{tabular}

Note: Bolded items indicate major loadings for each item.

The pattern coefficients show the factor loadings of each of the variables. The main loadings on Component 1 are FDR, AFF, IMDF, EFC, LAF, IMFWE and DUF. The items on Component 2 are UFP, RTDF, MAF, FCF and RCF. Communalities gives information about how much of the variance in each item is explained. IMFWE and DUF have .286 and .239 respectively on communalities. These two items have values that are less than \pm 0.30 , and also show the lowest loadings on Component 1 (.556 and .481). We may therefore use this information to remove the two items from the scale in order to increase the total variance explained, should a confirmatory factor analysis be contemplated. MAF (.733), UFP (.728), FDR (.629), and AFF (.602) have the highest coefficients.

\section{Summary of Findings}

The 12 items of the SFP scale were subjected to EFA analysis. Prior to performing EFA, the suitability of data for factor analysis was assessed. Inspection of the correlation matrix revealed the presence of many coefficients of .3 and above. The Kaiser-Meyer-Olkin value was .86, exceeding the recommended value of .6 (Kaiser 1970; 1974) and Bartlett's Test of Sphericity (Bartlett 1954) reached statistical significance, supporting the factorability of the

Ibiyemi A, Adnan Y M, Daud M N \& Adenipekun M. 2014, 'An examination of the structure of facilities planning scale for user satisfaction in Nigerian universities’, Australasian Journal of Construction Economics and Building, 14(3), 58-73. 
correlation matrix. Principal components analysis revealed the presence of four components with eigenvalues exceeding 1, explaining $38.28 \%, 11.67 \%, 9.26 \%$ and $8.56 \%$ of the variance respectively. An inspection of the screeplot revealed a break after the second component. Using Catell's (1966) scree test, it was decided to retain two components (components 1 and 2) for further investigation. This was further supported by the results of parallel analysis, which showed only two components with eigenvalues exceeding the corresponding criterion values for a randomly generated data matrix of the same size $(12$ variables $\times 600$ respondents). The two-component solution explained a total of $49.95 \%$ of the variance, with Component 1 contributing $31.25 \%$ and Component 2 contributing $17.0 \%$. To aid in the interpretation of these two components, oblimin rotation was performed. The rotated solution revealed the presence of simple structure, with both components showing a number of strong loadings and all variables loading substantially on the two components. There was a weak negative correlation between the two factors $(r=.464)$. The results of this analysis support the use of MAF, UFP, FDR, and AFF and these can be regarded as core determinants of SFP for user satisfaction in SW Nigeria Universities.

Findings from descriptive analysis were that locations of facilities were fairly suited to needs of users, and there is demand for use of facilities across the universities. Mean scores ranged from 2.8 to 3.3. Repairing condition is fair, but maintenance of facilities is not adequate. There is poor use of facilities planning in the management of their facilities, although functional connection of facilities to one another with respect to the needs of users is fair. Generally, all the universities have fairly adequate facilities to meet the needs of users. While the period of time it takes to respond to request to repair dysfunctional facilities needs to be optimised, the effect of condition of facilities on users' performance, and also that of facilities condition on their work efficiency are poor. These findings correlated moderately with the researchers' direct observations.

\section{Discussion}

The result of this study reveals high levels of components 1 (locational advantage and user needs) and 2 (facilities adequacy and functional connection) in the assessment of user satisfaction. The two-factor solution obtained in this study meets the expectations of the researcher by contributing an investigation into the factor structure of SFP which the researcher has been unable to find in extant and recent literature. The result suggests that modifications to the original structure of SFP are necessary when using the scale in a sample of students and staff of universities. Item 5 (DUF) should not be included in the calculation of the SFP scale because it has the lowest loadings of pattern and structure coefficients of .481 and .489 respectively (see Table 9). The adequacy of facilities and functional connection sub-scale remains consistent and can be used. It is evident that university management cannot afford to be negligent in considering student and staff viewpoints in their facilities planning operations, as most decisions have direct implications for user comfort and satisfaction, and can also be a catalyst for performance improvement of the universities. Empirically, the result justifies the importance of FP as a user-focused tool. However, it has been argued that the respondents might not have adequate knowledge about the overall facilities within the universities. The possible response to this is that the students and staff are informed respondents, who despite possibly having limited access to records relating to facilities, budgeting, and space allocation issues, can nevertheless perceive relationships between these facilities, and how the resource use and allocation have enhanced or diminished their comfort and satisfaction. Their perception, when recorded on the appropriate scale, provides a reliable data set summary which can be triangulated for internal validity. If SFP is well designed and implemented in a stakeholder-integrated fashion that optimises resource use, the corresponding positive effects will resonate even at the lowest levels of

Ibiyemi A, Adnan Y M, Daud M N \& Adenipekun M. 2014, 'An examination of the structure of facilities planning scale for user satisfaction in Nigerian universities’, Australasian Journal of Construction Economics and Building, 14(3), 58-73. 
management. The study agrees with Steiss (2005) that contribution to the discussion on factor structure of sustainable facilities planning scale should be demonstrated and documented.

\section{Conclusion}

It is desirable that strategic and sustainable facilities planning in universities factor studentstaff focus points into facilities maintenance management, costs in use, space and general operations planning through an open feedback mechanism. If it does not, optimum university service delivery for organisational effectiveness cannot be expected. Structure details could be generalised while specific details could vary from campus to campus. This implies continual clarification of the structure characteristics for documentation in a manner that engenders a reliable information base. The aim and purpose of the study, to specify the structure of sustainable facilities planning scale in relation to student-staff user satisfaction by identifying the underlying factors and variables inter-relationships, has been achieved. The research questions have been answered. The two underlying factors have been determined, and the interrelationships among the variables explained. The study compares favourably with Steiss (2005), but goes further to propose the student-staff dimension as its main contribution to knowledge and practice. The utilisation of factor analysis as an effective technique to elicit dominant factors in a scale is in concordance with extant and recent literature which enabled the scales and sub-scales to be examined. Importantly, the need to understand the underlying factors underscores the relevance of sustainable facilities planning to user satisfaction, and could provide a platform to operationalise sustainable facilities planning practices for organisational effectiveness. This paper concludes that a wellstructured study could also provide empirical information as a life belt for best practices in management planning, physical plant planning, financial planning, total institutional plan, and evaluation of facilities program, response timing, and annual facilities review. The levels of Factors 1 and 2 detected and accepted suggest that they are dominant factors in the sustainable facilities planning scale. However, researchers who are considering using it in a sample of students and staff of universities should flexibly adjust the sub-scale to the climes of the university under their study. EFA supported the presence of the two sub-scales, but suggests that item 5 be removed. The new direction of thinking about the research problem should be to integrate student-staff viewpoints into universities' facility plans as a corollary to community involvement, and the optimisation of facilities use through structured reevaluation of design and strategies. The respondents were constrained by limited access to classified information, such as facilities acquisition plans and costs. Although, such limitations may impinge on scope for generalisation, they are ineffectual in altering the reliability and validity of the findings. Further research will be necessary to establish cut-off points for a revised one item factor 1 by triangulating with a structured interview.

\section{References}

Addae-Dapaah, K, Hiang, L.K \& Shi, N. Y. 2009, 'Sustainability of sustainable real property development', Journal of Sustainable Real Estate, 1 (1), 203-225.

Adegoke, B.F. \& Adegoke, O.J.T. 2013, 'The use of facilities management in tertiary institutions in Osun State, Nigeria', Journal of Facilities Management 11 (2), 183-192.

Adewunmi, Y, Omirin, M. \& Koleoso, H. 2012, 'Developing a sustainable approach to corporate FM in Nigeria', Facilities 30 (9), 350-373.

Amaratunga, D. \& Baldry, D. 2000, 'Assessment of facilities management performance in higher education properties', Facilities, 18 (7/8), 293-301.

American Institute of Architects 2011, The Architect's handbook of professional practice, USA, AIA.

Ibiyemi A, Adnan Y M, Daud M N \& Adenipekun M. 2014, 'An examination of the structure of facilities planning scale for user satisfaction in Nigerian universities’, Australasian Journal of Construction Economics and Building, 14(3), 58-73. 
Association of School Business Officials International, ASBO 2003, 'Planning Guide for maintaining School Facilities', http://www.ed.gov/pubs/edpubs.html, Accessed 2 September 2014.

Atkin, B. \& Brooks, A. 2000, Total facilities management, Blackwell, Oxford, UK.

Barret, P.S. \& Baldry, D. 2003, Facilities management: Towards best practice, Blackwell, Oxford, UK.

Bartlett, M.S. 1954, 'A note on the multiplying factors for various chi square approximations', Journal of the Royal Statistical Society, 16 (Series B), 296-298.

Bitner, M.J. 1992, 'Services capes: The impact of physical surroundings on customers and employees', Journal of Marketing, 56 (3), 57-71.

Burud, S. 2010, Working out of the box, Facilities Management Resource, FMLink Online, Retrieved from www.FMJONLINE.com, Accessed 16 August 2014.

Catell, R.B. 1966, 'The scree test for number of factors', Multivariate Behavioral Research, 1 (2), 245276.

Chotipanich, S. \& Nutt, B. 2008, 'Positioning and repositioning FM', Facilities, 26 (9/10), 374-378.

De Toni, A.F, Fornasier, A, Montagner, M. \& Nonino, F. 2007, 'A performance measurement system for facility management: The case study of a medical service authority'. International Journal of Productivity and Performance Management, 56, 5/6 417/435.

De Vries, J.C, De Jonge, H. \& Van Der Voordt, T.J.M. 2008, 'Impact of real estate interventions on organisational performance', Journal of Corporate Real Estate, 10 (3), 208-223.

Devellis, R.F. 2003, 'Scale development: Theory and applications', Thousand Oaks, California, Sage.

Fareo, D. \& Ojo, O. 2013, 'Impact of facilities on academic performance of students with special needs in mainstreamed public schools in Southwestern Nigeria', Journal of Research in Special Educational Needs, 13 (2), 159-167.

Field, A. 2009, 'Discovering statistics using SPSS', Thousand Oaks, California, Sage.

Herman B, Kok, M.P. \& Mobach Onno S.W 2011, 'Facilities design', Journal of Facilities Management, 9 (4), 249-265.

Ho, R. 2006, Handbook of univariate and multivariate data analysis and interpretation with SPSS, Taylor \& Francis, US.

Howitt, D. \& Crammer, D. 2011, Introduction to SPSS statistics in psychology: For versions 19 and earlier, Pearson, Edinburg, UK.

IFMA 2009, The strategic facility planning: A white paper, International Facilities Management Association, UK.

IJFM 2010, A model of workplace environment satisfaction: A survey instrument, FMLink, Facilities management resources, United Kingdom.

JAMB 2010, Joint admissions and matriculations board, eBROCHURE, Joint Admissions Matriculations Board, Abuja, Nigeria.

Kaiser, H. 1970, 'A second generation Little Jiffy', Psychometrika, 35 (4), 401-415.

Kaiser, H. 1974, 'An index of factorial simplicity'. Psychometrika, 39 (1), 31-36.

Kline, T.J.B. 2005, 'Psychological testing: A practical approach to design and evaluation', Thousand Oaks, California, Sage.

Koppelman, J.D.C.L, In Lawal (2000), Ile-Ife, ILCO Books Publishers, 'Urban planning and design criteria', In: Lawal, M.I, (ed), Estate development practice in Nigeria, 1975 ILCO Books, Nigeria.

Krizek, K.J, Newport, D, White, J. \& Townsend, A.R. 2012, 'Higher education's sustainability imperative: how to practically respond?' International Journal of Sustainability in Higher Education, 13 (1), 19-33.

Krumm, P.J.M, Dewulf, G. \& De Jonge, H. 1998, 'Managing key resources and capabilities: pinpointing the added value of corporate real estate management', Facilities, 16 (12/13), 372-379.

Ibiyemi A, Adnan Y M, Daud M N \& Adenipekun M. 2014, 'An examination of the structure of facilities planning scale for user satisfaction in Nigerian universities', Australasian Journal of Construction Economics and Building, 14(3), 58-73. 
Lepkova, N. \& Uselis, R. 2013, 'Development of a quality criteria system for facilities management services in Lithuania', Procedia Engineering, 57, 697-706, DOI: 10.1016/j.proeng.2013.04.088.

Lindholm, A.L. \& Levainen, K.I. 2006, 'A framework for identifying and measuring value added by corporate real estate', Journal of Corporate Real Estate, 8 (1), 38-46.

Marmolejo, F. 2007, Higher education facilities: Issues and trends: OECD.

National Universities Commission (NUC) 2011, List of accredited universities in Nigeria: National Universities Commission.

Olesand, N. 2010, The evolving workspace, Facilities Management Resources, Available info@failink.com, Accessed 15 August 2014.

Oven, D. \& Pekdemir, A. 2006, 'Office rent determinants utilizing factor analysis', Journal of Real Estate Finance and Economics, 33, 51-73, doi: http://dx.doi.org/ 10.1007/s11146-006-8274-5.

Pallant, J. 2011, SPSS survival manual, Allen \& Unwin, NSW.

Pallant, J. \& Bailey, C. 2005, 'Assessment of the structure of the hospital anxiety and depression scale in musculoskeletal patients', Health and Quality of Life Outcomes, 3 (82).

Paxman, D. 2007, Facilities Management in practice, IFPI Ltd. Kent, UK.

Robathan, P. 1996, Intelligent building performance facility management: Theory and practice, Spon Press, London.

Rondeau, E.P, Brown, R.K. \& Lapides, P.D. 1995, Facility Management, John Wiley \& Sons NY.

Salonen, A. 2004, 'Managing outsourced support services: observations from case study', Facilities, $22(11 / 12), 317-322$.

Sawyer, P.T. \& Yusof, N.A. 2013, 'Students satisfaction with hostel facilities in Nigerian Polytechnics', Journal of Facilities Management, 11 (4), 306-322.

Sekula, M. 2010, 'Strategic facility planning: Now more important than ever', Facilities management resources, Facilities Management Journal

Shayler, S. 2010, 'Calculating for change', Facilities management resource

Somorova, V. 2007, 'The task of the facility management in real estate development', Vadyba/Management $\mathrm{m}, 16-17$ (3/4).

Steiss, A. 2005, Strategic facilities planning: Capital budgeting and debt administration, Google books, UK.

Tabachnick, B.G. \& Fidell, L.S. 2007, Using multivariate statistics, Pearson Education, Boston, USA.

UNM 2014, University of New Mexico planning and campus development.

Van Mell, D. 2005, What is facility plan? Available: http://www.vanmell.com/Articles/whatisafacilityplan.pdf, Accessed on 2 September 2014.

Vossler, C.A. \& Kerkvliet, J. 1999, 'A criterion validity test of the contingent valuation method: Comparing hypothetical and actual voting behaviors for a public referendum', Journal of Environmental Economics and Management 45 (2003), 631-649.

Wauters, B. 2005, 'The added value of facilities management: benchmarking work processes', Facilities, 23 (3/4) 142-151.

Williams, B. 1996, 'Cost-effectiveness facilities management: A practical approach', Facilities, 14 (5/6), 26-38.

Wright, R. \& Olesand, N. 2007, Paradigm shifts in property management and work, Work place trends: Managing New Work Styles, London.

Zeemering, E. 2009, 'What does sustainability mean to city officials?' Urban Affairs Review, 45, 247273, doi: http://dx.doi.org/.1177/1078087409337297.

Ibiyemi A, Adnan Y M, Daud M N \& Adenipekun M. 2014, 'An examination of the structure of facilities planning scale for user satisfaction in Nigerian universities', Australasian Journal of Construction Economics and Building, 14(3), 58-73. 